Jurnal Ilmu Ilmu Agribisnis: Journal of Agribusiness Science, 9(4), November 2021

\title{
ANALISIS KELAYAKAN FINANSIAL USAHA SAPI PERAH SENTULFRESH INDONESIA DI KABUPATEN BOGOR
}

\author{
(Financial Feasibility Analysis of Dairy Cattle Sentulfresh Indonesia in Bogor Regency)
}

Siska Aprilia, Fembriarti Erry Prasmatiwi, Achdiansyah Soelaiman

Jurusan Agribisnis, Fakultas Pertanian, Universitas Lampung, Jl. Prof. Dr. Soemantri Brojonegoro No. 1
Bandar Lampung 35145, e-mail: fembriarti.erry@fp.unila.ac.id

\begin{abstract}
This research seeks to analyze the feasibility of dairy cattle business. This research was conducted in Sentulfresh Indonesia in Bogor Regency. Respondents consisted of the owner and the employees of dairy farm also yoghurt production. Data were analyzed by quantitatively using measurement criteria of financial viability and sensitivity analyzes. The results showed that dairy cattle business is financially viable as indicated by NPV values of Rp5,542,458,138.00; Net B/C values of 2.42; Gross B/C values of 1.63; IRR values of 35.09 percent; and PP of 5.76 from the economic life of dairy cattle for eight years, and dairy cattle business is still viable despite the drop in yoghurt sales of 6.24 percent, the drop in milk sales of 45.60 percent, and an increase in cow maintenance cost of 5.88 percent.
\end{abstract}

Key words: dairy cattle, financial feasibility, sensitivity.

Received: 18 May $2020 \quad$ Revised: 17 June 2020

\section{PENDAHULUAN}

Sektor pertanian merupakan sektor yang berperan penting baik sebagai mata pencaharian maupun sebagai penopang pembangunan. Subsektor peternakan sebagai salah satu subsektor di sektor ini dikenal sebagai pemenuh kebutuhan konsumsi pangan atas produk pangan hewani. Sapi perah memiliki peran strategis dalam meningkatkan pendapatan penduduk dan peningkatan perekonomian nasional (Khafsah, Warsito, dan Prastiya 2018).

Pengembangan peternakan sapi perah di Indonesia pada dasarnya bertujuan meningkatkan produksi susu dalam negeri untuk mengantisipasi tingginya permintaan susu. Subsektor peternakan berperan menyediakan susu untuk memenuhi permintaan masyarakat akan kebutuhan sumber protein hewani yang bernilai gizi tinggi dan sebagai bahan baku industri. Oleh karena itu, usaha peternakan sapi perah dapat dijadikan salah satu alternatif yang menjanjikan nilai keuntungan di masa depan (Labodu, Wantasen, Massie, dan Oroh 2015).

Provinsi Jawa Barat menempati urutan ketiga dari lima provinsi populasi sapi perah tertinggi pada tahun 2014-2018. Populasi sapi perah di Provinsi Jawa Barat fluktuatif, dengan populasi tertinggi pada tahun 2014 sebesar 123.140 ekor. Peternakan sapi perah memiliki prospek yang baik untuk
Accepted:20 July 2020

DOI: http://dx.doi.org/10.23960/jiia.v9i4.5390

dikembangkan di provinsi ini (BPS Jawa Barat 2013-2019).

Selaras dengan populasi sapi di Indonesia, hasil utama dari sapi yang menjadi peranan penting subsektor peternakan adalah susu sapi. Provinsi Jawa Barat menempati urutan kedua dari lima provinsi produksi susu tertinggi tahun 2014-2018. Produksi susu segar di Provinsi Jawa Barat fluktuatif, dengan produksi susu tertinggi pada tahun 2016 sebesar 302.560 ton (BPS Jawa Barat 2013-2019).

Kabupaten Bogor menempati urutan keempat dari lima kabupaten populasi sapi perah tertinggi pada tahun 2012-2017. Populasi sapi perah di Kabupaten Bogor fluktuatif, dengan populasi tertinggi pada tahun 2015 sebesar 43.577 ekor (BPS Jawa Barat 2013-2019). Kabupaten Bogor terletak di antara pegunungan dan dataran tinggi, iklim dan cuaca yang sejuk, untuk ketersediaan pakan hijauan, sehingga pasokan pakan akan terjamin.

Banyaknya usaha peternakan sapi perah di Provinsi Jawa Barat ikut membantu dalam peningkatan produksi susu segar. Kabupaten Bogor menempati urutan keenam dari enam kabupaten produksi susu tertinggi pada tahun 2012-2017, dengan produksi susu tertinggi pada tahun 2017 sebesar 18.492.525 liter (BPS Jawa Barat 2013-2019). Ketersediaan lahan di Kabupaten Bogor dan keberadaan 
perusahaan pengolah susu merupakan faktor penunjang perkembangan peternakan sapi perah di daerah ini (Poetri, Basith, dan Wijaya 2016).

Salah satu perusahaan yang melakukan kegiatan tersebut adalah Sentulfresh Indonesia yang berlokasi di Kecamatan Sukaraja, Kabupaten Bogor, Jawa Barat. Sentulfresh Indonesia merupakan perusahaan bidang pertanian berintegrasi yang berdiri sejak tahun 1998. Hingga tahun 2019, perusahaan ini memiliki 4 unit usaha, yaitu unit usaha wisata edukasi, unit usaha yoghurt, unit usaha pondok pesantren, dan unit usaha bisnis online. Selain memiliki 4 unit usaha, perusahaan ini dilengkapi dengan peternakan sapi perah jenis Frissian holstein. Namun dalam perjalanan usahanya, Sentulfresh Indonesia mengalami kendala yang silih berganti, salah satunya adalah gagal menciptakan siklus kawin sapi pada tahun 2013 yang mengakibatkan pemilik merugi hingga puluhan juta rupiah.

Dalam kegiatan agribisnis sapi perah, Sentulfresh Indonesia menghadapi berbagai kendala yang menghambat jalannya usaha. Kendala tersebut berupa biaya investasi besar, harga bibit sapi yang mahal, kualitas bibit sapi yang menurun yang berdampak pada produksi susu tetapi perusahaan tidak ingin mengambil risiko untuk menambah sapi, jumlah bibit sapi yang banyak tidak sebanding dengan nilai susu dan berdampak pada jumlah bahan baku untuk produksi yoghurt. Berdasarkan uraian tersebut, penelitian ini bertujuan untuk mengkaji kelayakan finansial usaha sapi perah dan sensitivitas kelayakan usaha sapi perah di Sentulfresh Indonesia.

\section{METODE PENELITIAN}

Metode penelitian yang digunakan adalah studi kasus. Penelitian ini dilaksanakan pada Sentulfresh Indonesia di Kabupaten Bogor yang dipilih secara sengaja (purposive), dengan pertimbangan bahwa Sentulfresh Indonesia merupakan salah satu perusahaan berbasis integrated farming besar di Kabupaten Bogor. Responden untuk penelitian ini adalah pemilik serta karyawan peternakan sapi perah dan produksi yoghurt Sentulfresh Indonesia. Pengumpulan data dilakukan pada bulan Juli 2019.

Data yang dikumpulkan dalam penelitian ini adalah data primer dan data sekunder. Data primer diperoleh dari wawancara dan pengamatan langsung. Data sekunder diperoleh dari studi literatur, laporan penjualan susu sapi dan yoghurt Sentulfresh Indonesia, dan pustaka lainnya yang berhubungan dengan penelitian ini, serta lembaga/instansi yang terkait dalam penelitian ini, seperti Badan Pusat Statistik Jawab Barat, Badan Pusat Statistik Jakarta, Dinas Pertanian Provinsi Jawa Barat, dan lain-lain.

Analisis kelayakan finansial adalah analisis yang bertujuan menilai kelayakan suatu kegiatan investasi untuk dijalankan. Kriteria penilaian yang digunakan terdiri dari Net Present Value (NPV), Net B/C ratio, Gross B/C ratio, Internal Rate Return, dan Payback Period (Kadariah 2001). Umur proyek mengacu pada umur ekonomis sapi perah yaitu 8 tahun. Tingkat suku bunga yang digunakan yaitu bank BCA sebesar 9,75 persen atas dasar kredit korporasi. Net Present Value merupakan selisih antara present value dari penerimaan dengan present value dari pengeluaran. NPV dapat dirumuskan sebagai berikut.

$\mathrm{NPV}=\sum_{\mathrm{t}=1}^{\mathrm{n}} \frac{\mathrm{Bt}-\mathrm{Ct}}{(1-\mathrm{i})^{\mathrm{t}}}$

Keterangan:

$$
\begin{array}{ll}
\mathrm{Bt} & =\text { Benefit tahun } \mathrm{t} \\
\mathrm{Ct} & =\text { Cost tahun } \mathrm{t} \\
\mathrm{i} & =\text { Tingkat bunga }(9,75 \%) \\
\mathrm{t} & =\text { Umur ekonomis sapi perah (8 tahun) }
\end{array}
$$

Kriteria pengambilan keputusan:

1) Bila NPV > 0, maka usaha ternak sapi perah dinyatakan layak.

2) Bila NPV < 0, maka usaha ternak sapi perah dinyatakan tidak layak.

3) Bila NPV $=0$, maka usaha ternak sapi perah dinyatakan dalam posisi impas.

Net Benefit Cost Ratio (Net B/C) diperoleh dari perbandingan antara net benefit yang telah di discount positif dengan net benefit yang telah di discount negatif. Net $\mathrm{B} / \mathrm{C}$ dapat dirumuskan sebagai berikut.

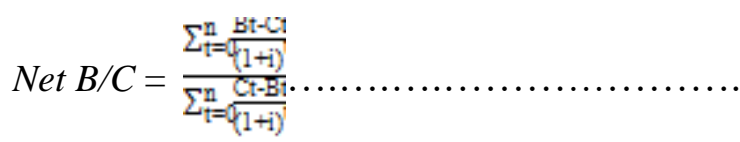

Keterangan:

$$
\begin{aligned}
& \text { Net } \mathrm{B} / \mathrm{C}=\text { Net Benefit Cost Ratio }(\mathrm{Rp}) \\
& \mathrm{Bt}=\text { Benefit tahun } \mathrm{t} \\
& \mathrm{Ct}=\text { Cost tahun } \mathrm{t} \\
& \mathrm{i}=\text { Tingkat bunga }(9,75 \%) \\
& \mathrm{t}=\text { Umur ekonomis sapi perah (8 tahun) }
\end{aligned}
$$


Kriteria penilaian Net Benefit Cost Ratio (Net $\mathrm{B} / \mathrm{C})$ :

1) Jika Net B/C > 1, maka usaha ternak sapi perah dinyatakan layak.

2) Jika $\mathrm{Net} \mathrm{B} / \mathrm{C}<1$, maka usaha ternak sapi perah dinyatakan tidak layak.

3) Jika Net $\mathrm{B} / \mathrm{C}=1$, maka usaha ternak sapi perah dinyatakan dalam posisi impas.

Gross Benefit Cost Ratio (Gross B/C) diperoleh dari perbandingan antara gross benefit dengan gross cost. Gross B/C dapat dirumuskan sebagai berikut.

Gross $B / C=\frac{\sum_{\mathrm{t}=0}^{\mathrm{n}} \frac{\mathrm{Bt}}{(1+\mathrm{i})^{\mathrm{t}}}}{\sum_{\mathrm{t}=0}^{\mathrm{n}} \frac{\mathrm{Ct}}{(1+\mathrm{i})^{\mathrm{t}}}}$

Keterangan:

$$
\begin{array}{ll}
\text { Gross B/C } & =\text { Gross Benefit Cost Ratio (Rp) } \\
\mathrm{Bt} & =\text { Benefit tahun } \mathrm{t} \\
\mathrm{Ct} & =\text { Cost tahun } \mathrm{t} \\
\mathrm{i} & =\text { Tingkat bunga }(9,75 \%) \\
\mathrm{t} & =\text { Umur ekonomis sapi perah }(8 \\
& \text { tahun })
\end{array}
$$

Kriteria penilaian Gross Benefit Cost Ratio (Gross $\mathrm{B} / \mathrm{C})$ :

1) Jika Gross B/C > 1, maka usaha ternak sapi perah dinyatakan layak.

2) Jika Gross B/C < 1, maka usaha ternak sapi perah dinyatakan tidak layak.

3) Jika Gross B/C = 1, maka usaha ternak sapi perah dinyatakan dalam posisi impas.

Internal Rate of Return (IRR) adalah suatu tingkat bunga yang menunjukkan nilai bersih sekarang (NPV) sama dengan jumlah seluruh investasi proyek atau dengan kata lain tingkat bunga yang menghasilkan NPV sama dengan nol. IRR dapat dirumuskan sebagai berikut.

$$
\begin{aligned}
& \mathrm{IRR}= \\
& \mathrm{i}_{1}+\frac{\mathrm{NPV}_{1}}{\mathrm{NPV}_{1}-\mathrm{NPV}_{2}}\left(\mathrm{i}_{2}-\mathrm{i}_{1}\right)
\end{aligned}
$$

Keterangan:

$$
\begin{array}{ll}
N P V_{1} & =\text { NPV positif } \\
N P V_{2} & =\text { NPV negatif } \\
i_{1} & =\text { Tingkat suku bunga } N P V_{1}
\end{array}
$$

$i_{2} \quad=$ Tingkat suku bunga $N P V_{2}$

Kriteria penilaian Internal Rate of Return (IRR):

1) Jika IRR > tingkat suku bunga, maka usaha ternak sapi perah dinyatakan layak.

2) Jika IRR < tingkat suku bunga, maka usaha ternak sapi perah dinyatakan tidak layak.

3) Jika IRR = tingkat suku bunga, maka usaha ternak sapi perah dinyatakan dalam posisi impas.

Payback Period (PP) merupakan penilaian investasi suatu proyek yang didasarkan pada pelunasan biaya investasi. Payback Period dapat dirumuskan sebagai berikut.

$\mathrm{PP}=\frac{\mathrm{K}_{0}}{\mathrm{~A}_{\mathrm{b}}} \times 1$ tahun

Keterangan:

$K_{0} \quad=$ Investasi awal

$A_{b} \quad=$ Manfaat yang diperoleh setiap periode

Kriteria penilaian Payback Period (PP):

1) Jika Payback Period < umur ekonomis sapi perah, maka usaha ternak sapi perah dinyatakan layak.

2) Jika Payback Period > umur ekonomis sapi perah, maka usaha ternak sapi perah dinyatakan tidak layak.

Analisis sensitivitas atau laju kepekaan dilakukan untuk mengetahui sejauh mana dampak parameterparameter investasi yang telah diterapkan sebelumnya boleh berubah, karena adanya faktor situasi dan kondisi selama umur investasi, sehingga perubahan tersebut hasilnya akan berpengaruh secara signifikan pada keputusan yang telah diambil (Giatman 2006). Tingkat kenaikan biaya suatu produksi akan menyebabkan nilai NPV, Gross B/C, Net B/C dan IRR tidak menguntungkan. Selain itu, perlu juga dihitung setiap penurunan harga jual suatu produk jadi yang menyebabkan beberapa kriteria investasi menjadi tidak meyakinkan. Aspek analisis sensitivitas dalam penelitian ini diantaranya:

1) Apabila terjadi penurunan volume penjualan yoghurt sebesar 6,24 persen yang diasumsikan dari penurunan volume penjualan pada tahun 2017.

2) Apabila terjadi penurunan penjualan susu sebesar 45,60 persen yang diasumsikan dari penurunan penjualan susu pada tahun 2017. 
Tabel 1. Biaya investasi peternakan sapi perah dan produksi yoghurt Sentulfresh Indonesia

\begin{tabular}{|c|c|c|c|c|}
\hline Uraian & $\begin{array}{c}\text { Jlh } \\
\text { (unit) }\end{array}$ & $\begin{array}{l}\text { UE } \\
\text { (th) }\end{array}$ & $\begin{array}{c}\text { Harga } \\
\text { (Rp/unit) }\end{array}$ & $\begin{array}{c}\text { Total Biaya } \\
(\mathrm{Rp})\end{array}$ \\
\hline \multicolumn{5}{|c|}{ Usaha sapi perah } \\
\hline Kandang sapi & 1 & 9 & 200.000 .000 & 200.000 .000 \\
\hline Gudang & 1 & 9 & 50.000 .000 & 50.000 .000 \\
\hline $\begin{array}{l}\text { Pembelian sapi } \\
\text { perah }\end{array}$ & 60 & 8 & 25.000 .000 & 1.500 .000 .000 \\
\hline $\begin{array}{l}\text { Instalasi listrik } \\
\text { PLN }\end{array}$ & \multicolumn{3}{|c|}{ PLN } & 5.000 .000 \\
\hline Air shower & 1 & 10 & 3.000 .000 & 3.000 .000 \\
\hline Mobil pick up & 1 & 10 & 105.000 .000 & 105.000 .000 \\
\hline Milk can & 5 & 5 & 750.000 & 3.750 .000 \\
\hline Mesin pompa & 1 & 5 & 650.000 & 650.000 \\
\hline Total biaya investa & asi usaha & sapi pe & erah & 1.867 .400 .000 \\
\hline \multicolumn{5}{|c|}{ Usaha yoghurt } \\
\hline Rumah produksi & 1 & 6 & 100.000 .000 & 100.000 .000 \\
\hline Timbangan gula & 1 & 3 & 300.000 & 300.000 \\
\hline Mangkuk & 24 & 1 & 3.000 & 72.000 \\
\hline Sendok sayur & 24 & 1 & 1.500 & 36.000 \\
\hline $\begin{array}{l}\text { Kompor gas } 2 \\
\text { tungku }\end{array}$ & 2 & 5 & 1.500 .000 & 3.000 .000 \\
\hline Freezer box & 2 & 5 & 6.210 .000 & 12.420 .000 \\
\hline Freezer kecil & 3 & 5 & $\quad 8.000 .000$ & 24.000 .000 \\
\hline \multicolumn{5}{|c|}{$\begin{array}{c}\text { Total biaya investasi usaha yoghurt } \\
2.007 .228 .000\end{array}$} \\
\hline
\end{tabular}

3) Apabila terjadi kenaikan biaya perawatan sapi sebesar 5,88 persen yang diasumsikan dari kenaikan biaya perawatan sapi pada tahun 2018.

Laju kepekaan atau sensitivitas dihitung melalui rumus sebagai berikut.

Sensitivitas $=\frac{\left|\frac{X_{1}-X_{0}}{X}\right| \times 100 \%}{\left|\frac{Y_{1}-Y_{0}}{Y}\right| \times 100 \%}$

Keterangan:

$X_{1}=\mathrm{NPV}$, IRR, Net $\mathrm{B} / \mathrm{C}$ setelah terjadi perubahan

$X_{0} \quad=\mathrm{NPV}$, IRR, Net $\mathrm{B} / \mathrm{C}$ sebelum terjadi perubahan

$\mathrm{X}=$ Rata-rata perubahan NPV, IRR, Net B/C

$Y_{1} \quad=$ Harga jual/penjualan setelah terjadi perubahan

$Y_{0} \quad=$ Harga jual $/$ penjualan sebelum terjadi perubahan

$\mathrm{Y}=$ Rata-rata perubahan harga jual/penjualan

HASIL DAN PEMBAHASAN

\section{Profil Sentulfresh Indonesia}

Sentulfresh Indonesia adalah perusahaan berbasis pertanian berintegrasi yang menggabungkan peternakan, perikanan, dan pertanian menjadi satu pengelolaan di dalam lahan seluas 4,50 hektar. Perjalanan usaha dimulai dengan pembuatan kolam ikan dan memelihara ikan mas, bisnis berbagai macam burung berkicau, bisnis ayam broiler, hingga pengembangan bisnis Lele Sangkuriang. Saat ini, usaha yang dijalankan Sentulfresh Indonesia meliputi wisata edukasi, peternakan sapi perah serta produksi yoghurt.

\section{Usaha Sapi Perah Sentulfresh Indonesia}

Pada tahun 2010, peternakan sapi perah ditambahkan dalam unit usaha Sentulfresh Indonesia. Selanjutnya pada tahun 2011, pemilik mengelola usaha sapi perah dan pada tahun 2013, usaha ini dilakukan secara konsisten. Jumlah bibit sapi awal sebanyak 60 ekor sapi laktasi dan pada tahun 2019, jumlah sapi perah yang ada di peternakan sebanyak 35 ekor, yang terdiri dari 23 ekor sapi betina, 10 ekor sapi jantan dewasa, 1 ekor anakan sapi betina, dan 1 ekor anakan sapi jantan. Kegiatan yang dilakukan dalam unit usaha peternakan sapi perah adalah penyediaan sarana peternakan, pemeliharaan sapi perah, pengelolaan reproduksi, proses pemerahan serta produksi susu.

Pada tahun 2014, pemilik mendirikan unit usaha yoghurt Sentulfresh. Bahan baku yoghurt yaitu susu sapi diambil langsung dari sapi perah yang ada di peternakan sapi perusahaan. Produk ini terus berkembang dan pemilik sanggup memproduksi ice yoghurt dan fresh yoghurt sebanyak 12.000 kemasan/bulan. Kegiatan yang dilakukan dalam unit usaha produksi yoghurt adalah penyediaan sarana produksi, produksi yoghurt, pemasaran yoghurt, dan praktik pembuatan yoghurt untuk wisata edukasi.

\section{Biaya Usaha Sapi Perah Sentulfresh Indonesia}

Biaya usaha sapi perah adalah seluruh pengeluaran dalam usaha untuk menjalankan suatu proses produksi untuk membeli atau membayar input dan jasa-jasa yang digunakan dalam kegiatan produksi. Biaya tersebut terdiri dari biaya investasi yang dikeluarkan pada tahun-tahun awal dan biaya operasional yang berkaitan dengan biaya yang dikeluarkan dalam proses produksi.

\section{Biaya Investasi}

Biaya investasi merupakan biaya yang dikeluarkan pada tahun awal usaha sapi perah dilakukan. Biaya investasi pada usaha sapi perah Sentulfresh Indonesia dibagi menjadi dua, yaitu biaya investasi 
peternakan sapi perah dan biaya investasi produksi yoghurt. Total biaya investasi usaha sapi perah dan yoghurt adalah Rp2.007.228.000.

Kegiatan investasi pertama yang dilakukan dalam peternakan sapi perah adalah membangun kandang sapi. Perusahaan ini memiliki satu kandang sapi perah. Kegiatan investasi selanjutnya adalah pemilik membeli 60 ekor bibit sapi dara dan laktasi. Setelah itu, pemilik membeli peralatan seperti milk can dan mesin pompa serta melakukan instalasi listrik dan air shower. Penelitian ini seperti pernah dilakukan oleh Pahlevi, Zakaria, dan Kalsum (2014), bahwa biaya investasi terdiri dari biaya pembuatan kandang, mesin, dan peralatan. Total biaya investasi peternakan sapi perah adalah Rp1.867.400.000.

Kegiatan investasi pertama yang dilakukan dalam produksi yoghurt adalah membangun rumah produksi. Kegiatan investasi selanjutnya adalah pemilik membeli peralatan produksi antara lain timbangan gula, mangkuk, sendok sayur, kompor 2 tungku, freezer box, dan freezer kecil. Investasi produksi yoghurt adalah Rp139.828.000.

\section{Biaya Operasional}

Biaya operasional adalah semua biaya yang berhubungan langsung dengan kegiatan usaha sapi perah. Biaya operasional dibagi menjadi biaya operasional peternakan sapi perah dan biaya operasional produksi yoghurt.

Tabel 2. Biaya pakan dan perawatan peternakan sapi perah Sentulfresh Indonesia per 1 ekor

\begin{tabular}{lrrr}
\hline Keterangan & $\begin{array}{c}\text { Harga } \\
\text { (Rp/unit) }\end{array}$ & $\begin{array}{c}\text { Total biaya (Rp) } \\
\text { (unit) }\end{array}$ & $\begin{array}{c}\text { Biaya } \\
\text { (Rp) }\end{array}$ \\
\hline $\begin{array}{l}\text { Konsentrat } \\
\text { (kg) }\end{array}$ & 2.479 & 19 & 47.101 \\
$\begin{array}{l}\text { Ampas tahu } \\
\text { (kg) }\end{array}$ & 720 & 30 & 21.600 \\
Rumput (kg) & 300 & 40 & 12.000 \\
\hline Jumlah biaya pakan & & & 80.701 \\
\hline $\begin{array}{l}\text { Betadine 50 } \\
\text { ml (botol) }\end{array}$ & 1.500 & 1 & 1.500 \\
$\begin{array}{l}\text { Medoxy L } \\
\text { (botol) }\end{array}$ & 1.975 & 1 & 1.975 \\
$\begin{array}{l}\text { Gusanex } \\
\text { (botol) }\end{array}$ & 6.240 & 1 & 6.240 \\
$\begin{array}{l}\text { Suntik (box) } \\
\text { Alat infus } \\
\text { (unit) }\end{array}$ & 500 & 1 & 500 \\
$\begin{array}{l}\text { Inseminasi } \\
\text { buatan (orang) }\end{array}$ & 50.000 & 1 & 50.000 \\
\hline Jumlah biaya perawatan & & & 50.000 \\
\hline Total biaya pakan dan perawatan & & 110.215 \\
\hline
\end{tabular}

Tabel 3. Total biaya operasional peternakan sapi perah Sentulfresh Indonesia

\begin{tabular}{crrr}
\hline Thn & \multicolumn{3}{c}{ Total biaya (Rp) } \\
\cline { 2 - 4 } & $\begin{array}{c}\text { Biaya } \\
\text { investasi (Rp) }\end{array}$ & $\begin{array}{c}\text { Biaya } \\
\text { operasional } \\
(\mathrm{Rp})\end{array}$ & $\begin{array}{c}\text { Total biaya } \\
(\mathrm{Rp})\end{array}$ \\
\hline 1 & 1.759 .400 .000 & 77.470 .700 & 1.836 .870 .700 \\
2 & 108.000 .000 & 74.204 .708 & 182.204 .708 \\
3 & 0 & 73.116 .044 & 73.116 .044 \\
4 & 0 & 73.660 .376 & 73.660 .376 \\
5 & 0 & 73.745 .624 & 73.745 .624 \\
6 & 4.400 .000 & 75.266 .120 & 79.666 .120 \\
7 & 0 & 72.731 .960 & 72.731 .960 \\
8 & 0 & 70.704 .632 & 70.704 .632 \\
\hline
\end{tabular}

Biaya-biaya yang menjadi komponen utama, yaitu biaya pakan, perawatan sapi, peralatan peternakan, dan tenaga kerja.

Faktor produksi dalam budidaya sapi perah adalah perawatan sapi, terdiri dari pakan, obat-obatan, vitamin dan inseminasi buatan, seperti pernah dilakukan oleh Mona, Lestari, dan Situmorang (2014). Biaya pakan dan perawatan dihitung sesuai jumlah sapi per tahun.

Peralatan yang digunakan adalah sikat, serokan, garukan, dorongan, sapu, selang, dan saringan susu dan dihitung untuk seluruh sapi. Tenaga kerja berasal dari tenaga kerja luar keluarga dan termasuk tenaga kerja tetap. Terdapat 8 orang pada tahun 2013-2016 dan 7 orang pada tahun 2017-2020, dan biaya tenaga kerja dihitung sesuai jumlah sapi per tahun. Biaya lain yang dikeluarkan diantaranya pajak, listrik, dan, bahan bakar dan dihitung per tahun.

Biaya-biaya yang menjadi komponen utama dalam produksi yoghurt, yaitu biaya produksi, biaya peralatan, dan biaya tenaga kerja. Faktor produksi dalam produksi yoghurt adalah susu sapi, bakteri, pewarna makanan, gula pasir, dan air galon yang dihitung per tahun.

Peralatan yang digunakan adalah baskom, saringan, plastik packing, plastik yoghurt, dan botol $250 \mathrm{ml}$ dan dihitung per tahun. Tenaga kerja berasal dari tenaga kerja luar keluarga sebanyak 18 orang pada tahun 2013-2016 dan 17 orang pada tahun 2017-2020. Tenaga kerja produksi yoghurt termasuk harian. Biaya tenaga kerja dihitung per tahun. Biaya lain yang dikeluarkan diantaranya listrik freezer dan gas elpiji $12 \mathrm{~kg}$ dan dihitung per tahun. 
Tabel 4. Kebutuhan produksi yoghurt Sentulfresh Indonesia per 1 kali produksi

\begin{tabular}{|c|c|c|c|}
\hline \multirow[t]{2}{*}{ Keterangan } & \multirow{2}{*}{$\begin{array}{c}\text { Harga } \\
\text { (Rp/unit) }\end{array}$} & \multicolumn{2}{|c|}{ Total biaya (Rp) } \\
\hline & & $\begin{array}{l}\text { Jumlah } \\
\text { (unit) }\end{array}$ & Biaya (Rp) \\
\hline Susu sapi (l) & 5.000 & 12 & 60.000 \\
\hline Bakteri (box) & 50.000 & 1 & 50.000 \\
\hline $\begin{array}{l}\text { Pewarna makanan } \\
\text { anggur (botol) }\end{array}$ & 10.500 & 2 & 21.000 \\
\hline $\begin{array}{l}\text { Pewarna makanan } \\
\text { melon (botol }\end{array}$ & 10.500 & 2 & 21.000 \\
\hline $\begin{array}{l}\text { Pewarna makanan } \\
\text { leci (botol) }\end{array}$ & 10.500 & 2 & 21.000 \\
\hline $\begin{array}{l}\text { Pewarna makanan } \\
\text { stroberi (botol) }\end{array}$ & 10.500 & 2 & 21.000 \\
\hline $\begin{array}{l}\text { Pewarna makanan } \\
\text { jeruk (botol) }\end{array}$ & 10.500 & 2 & 21.000 \\
\hline Gula pasir (kg) & 12.150 & 4 & 48.600 \\
\hline Air (1) & 16.000 & 8 & 128.000 \\
\hline Jumlah biaya produ & & & 11.748 .000 \\
\hline
\end{tabular}

\section{Penerimaan Usaha Sapi Perah}

Produk yang dihasilkan dari ternak sapi perah berupa susu segar original dan olahan susu berupa es yoghurt dan yoghurt botol. Penerimaan utama usaha sapi perah Sentulfresh Indonesia diperoleh dari total penjualan susu segar dan olahan susu dikali harga. Tahun 2019 dan 2020 dilakukan proyeksi berdasarkan jumlah penjualan di tahun sebelumnya, seperti pernah dilakukan oleh Alfizar, Hasyim, dan Affandi (2017).

a. Penerimaan yoghurt

Yoghurt mulai menjadi sumber penerimaan pada tahun 2014. Tahun 2018 penjualan yoghurt mengalami penurunan 6,24 persen yang dikarenakan menurunnya permintaan distributor. Yoghurt dijual dengan harga Rp10.000 per pack dan per botol. Yoghurt mulai menjadi sumber penerimaan pada tahun 2014. Tahun 2018 penjualan yoghurt mengalami penurunan 6,24 persen sebab menurunnya permintaan distributor.
Tabel 5. Total biaya operasional produksi yoghurt Sentulfresh Indonesia

\begin{tabular}{crrr}
\hline Tahun & $\begin{array}{c}\text { Total biaya } \\
\text { investasi (Rp) }\end{array}$ & $\begin{array}{c}\text { Total biaya } \\
\text { operasional } \\
(\mathrm{Rp})\end{array}$ & $\begin{array}{c}\text { Total biaya } \\
(\mathrm{Rp})\end{array}$ \\
\hline 1 & 139.828 .000 & 0 & 139.828 .000 \\
2 & 108.000 & 267.459 .200 & 267.567 .200 \\
3 & 108.000 & 496.818 .800 & 496.926 .800 \\
4 & 408.000 & 593.093 .200 & 593.501 .200 \\
5 & 108.000 & 501.481 .100 & 501.589 .100 \\
6 & 108.000 & 459.400 .850 & 459.508 .850 \\
7 & 39.528 .000 & 664.191 .400 & 703.719 .400 \\
8 & 408.000 & 675.412 .800 & 675.820 .800 \\
\hline
\end{tabular}

Yoghurt dijual dengan harga Rp10.000 per pack dan per botol.

\section{b. Penerimaan sapi afkir}

Sapi afkir adalah sapi yang usianya sudah 8 tahun dan produksi susu sedikit. Harga sapi afkir adalah Rp10.000.000 per ekor dan tidak dijual setiap tahunnya. Jumlah sapi afkir pada tahun 8 diketahui dari nilai penjualan sapi yang menjadi benefit sapi afkir.

\section{c. Penerimaan susu segar original}

Susu sapi menjadi sumber penerimaan pada tahun 2014. Penjualan susu botol pada tahun 2017 mengalami penurunan sebesar 45,60 persen dan tahun 2018 mengalami penurunan sebesar 19 persen, dikarenakan menurunnya permintaan distributor.

\section{Analisis Finansial Usaha Sapi Perah}

Penilaian kriteria investasi untuk usaha sapi perah didasarkan atas umur usaha sapi perah yaitu 8 tahun pada tingkat suku bunga kredit korporasi Bank Central Asia sebesar 9,75 persen, seperti pernah dilakukan oleh penelitian Dinata, Zakaria, dan Endaryanto (2018).

Tabel 6. Penerimaan usaha sapi perah Sentulfresh Indonesia

\begin{tabular}{|c|c|c|c|c|}
\hline \multirow[t]{2}{*}{ Tahun } & \multicolumn{3}{|c|}{ Penerimaan (Rp) } & \multirow[t]{2}{*}{ Total penerimaan $(\mathrm{Rp})$} \\
\hline & Susu segar original & Yoghurt & Sapi afkir & \\
\hline 2013 & 0 & 0 & 0 & 0 \\
\hline 2014 & 405.000 & 264.660 .000 & 0 & 265.065 .000 \\
\hline 2015 & 180.000 & 1.376 .630 .000 & 0 & 1.376 .810 .000 \\
\hline 2016 & 1.930 .000 & 2.259 .860 .000 & 0 & 2.261 .790 .000 \\
\hline 2017 & 1.050 .000 & 1.712 .200 .000 & 0 & 1.713 .250 .000 \\
\hline 2018 & 850.000 & 1.605 .310 .000 & 0 & 1.606 .160 .000 \\
\hline 2019 & 1.524 .667 & 2.528 .350 .000 & 0 & 2.529 .874 .667 \\
\hline 2020 & 1.645 .111 & 2.770 .190 .000 & 40.000 .000 & 2.811 .835 .111 \\
\hline
\end{tabular}


Tabel 7. Analisis finansial usaha sapi perah Sentulfresh Indonesia

\begin{tabular}{lr}
\hline \multicolumn{1}{c}{ Kriteria } & \multicolumn{1}{c}{ Nilai } \\
\hline NPV & Rp5.542.458.138 \\
Net B/C & 2,42 \\
Gross B/C & 1,63 \\
IRR & $35,09 \%$ \\
PP & 5,76 \\
\hline
\end{tabular}

Nilai kriteria analisis finansial selama umur ekonomis sapi perah 8 tahun menunjukkan semua kriteria finansial layak diusahakan sesuai penelitian Rianzani, Kasymir, dan Affandi (2018).

Hasil penelitian ini tidak sejalan dengan penelitian Labodu, et al. (2015) karena terdapat perbedaan hasil antara Sentulfresh Indonesia dan Kelompok Ramulu Sangkor, yang tidak melakukan perhitungan payback period. Hasil perhitungan analisis finansial dapat dilihat pada Tabel 7.

\section{Analisis Sensitivitas}

Analisis sensitivitas dilakukan dengan mengubah nilai dari suatu parameter untuk dilihat pengaruhnya terhadap suatu alternatif investasi. Perubahan yang dikaji pada penelitian ini yaitu apabila terjadi penurunan volume penjualan yoghurt sebesar 6,24 persen,

Tabel 8. Analisis sensitivitas usaha sapi perah Sentulfresh Indonesia

\begin{tabular}{|c|c|c|c|c|}
\hline Kriteria & Sebelum & Setelah & LK & Ket. \\
\hline \multicolumn{5}{|c|}{ Penurunan penjualan yoghurt $(6,24 \%)$} \\
\hline NPV & 5.542 .458 .1 & 4.651 .216$. & $-2,7148$ & TS \\
\hline (Rp) & 38 & 673 & & \\
\hline Net $\mathrm{B} / \mathrm{C}$ & 2,42 & 2,29 & 14,6832 & $\mathrm{~S}$ \\
\hline Gross & 1,63 & 1,53 & 14,5599 & $\mathrm{~S}$ \\
\hline \multicolumn{5}{|l|}{$\mathrm{B} / \mathrm{C}$} \\
\hline $\operatorname{IRR}(\%)$ & $35,09 \%$ & $31,64 \%$ & 13,9989 & $\mathrm{~S}$ \\
\hline PP(thn) & 5,76 & 6,13 & 16,5067 & $\mathrm{~S}$ \\
\hline \multicolumn{5}{|c|}{ Penurunan penjualan susu $(45,60 \%)$} \\
\hline NPV & 5.542 .458 .1 & 5.538 .500 & 0,0012 & $\mathrm{TS}$ \\
\hline (Rp) & 38 & 688 & & \\
\hline Net $\mathrm{B} / \mathrm{C}$ & 2,42 & 2,42 & 0,0008 & TS \\
\hline Gross & 1,63 & 1,63 & 0,0005 & TS \\
\hline \multicolumn{5}{|l|}{$\mathrm{B} / \mathrm{C}$} \\
\hline IRR (\%) & $35,09 \%$ & $23,08 \%$ & 0,6994 & TS \\
\hline PP (thn) & 5,76 & 5,76 & $-0,0005$ & TS \\
\hline \multicolumn{5}{|c|}{ Kenaikan biaya perawatan sapi $(5,88 \%)$} \\
\hline NPV & 5.542 .458 .1 & 5.025 .877 & $-1,7115$ & TS \\
\hline (Rp) & 38 & 633 & & \\
\hline Net $\mathrm{B} / \mathrm{C}$ & 2,42 & 2,21 & $-1,5958$ & TS \\
\hline Gross & 1,63 & 1,54 & $-1,0000$ & TS \\
\hline \multicolumn{5}{|l|}{$\mathrm{B} / \mathrm{C}$} \\
\hline $\operatorname{IRR}(\%)$ & $35,09 \%$ & $20,29 \%$ & $-9,3550$ & TS \\
\hline PP (thn) & 5,76 & 6,09 & 0,9832 & TS \\
\hline
\end{tabular}

apabila terjadi penurunan penjualan susu sebesar 45,60 persen, dan apabila terjadi kenaikan biaya perawatan sapi sebesar 5,88 persen. Analisis sensitivitas penelitian disesuaikan dengan penelitian Poetri, et al. (2014). Hasil analisis sensitivitas menunjukkan kriteria pertama $\mathrm{Net} \mathrm{B} / \mathrm{C}$, Gross B/C, IRR, dan PP sensitif sedangkan NPV tidak sensitif. Pada kriteria kedua dan ketiga NPV, Net B/C, Gross B/C, IRR, dan PP tidak sensitif. Usaha sapi perah tidak layak dilanjutkan jika terjadi penurunan penjualan yoghurt sebesar 6,24 persen, penurunan penjualan susu sebesar 45,60 persen, dan kenaikan biaya perawatan sapi sebesar 5,88 persen.

Hasil penelitian ini sejalan dengan penelitian Chandra, Bakar, dan Kurniawan (2016) bahwa terdapat kesamaan pada kriteria analisis sensitivitas, yaitu menghitung kenaikan harga susu sapi. Namun hasil penelitian ini tidak sejalan dengan penelitian Khafsah, et al. (2018) karena tidak dilakukan perhitungan Gross B/C dan Net $B / C$. Hasil perhitungan analisis sensitivitas dapat dilihat pada Tabel 8 .

Dalam penelitian ini ada dua keterbatasan yang perlu disampaikan: Lingkup penelitian terbatas pada satu bagian usaha, yaitu usaha sapi perah sehingga hasil penelitian tidak digeneralisasikan, dan; Sentulfresh merupakan perusahaan yang menjalankan bidang jasa, yaitu wisata edukasi sehingga untuk melengkapi kegiatan wisata edukasi, dibutuhkan peternakan sapi perah.

\section{DAFTAR PUSTAKA}

Alfizar S, Hasyim AI, dan Affandi MI. 2017. Kelayakan finansial dan prospek pengembangan agribisnis sengon (Albazia falcataria) rakyat di Kecamatan Kemiling Kota Bandar Lampung. Jurnal Ilmu Ilmu Agribisnis, $\quad$ 5(3): 228-234. http://jurnal.fp.unila.ac.id/index.php/ JIA/article/view/1634/1460. [03 Juni 2020]

BPS [Badan Pusat Statistik] Jakarta. 2019a. Populasi Sapi Perah Menurut Provinsi. BPS Jakarta. Jakarta. .2019b. Perkembangan Produksi Susu Segar Menurut Provinsi. BPS Jakarta. Jakarta.

BPS [Badan Pusat Statistik] Jawa Barat. 20132019. Provinsi Jawa Barat Dalam Angka. Jawa Barat.

Chandra AC, Bakar A, dan Kurniawan D. 2016. 
Analisis kelayakan usaha pengolahan susu sapi di Kota Wisata Batu Malang. Reka Integra, 4 (2): 219-230. https://ejurnal. itenas.ac.id/index.php/rekaintegra/article/view /1103/1328. [10 April 2020]

Dinata RA, Zakaria WA, dan Endaryanto T. 2018. Analisis kelayakan finansial usaha penggilingan padi keliling di Kabupaten Pringsewu Provinsi Lampung. Jurnal Ilmu Ilmu Agribisnis, 6 (2): 163-170. http://jurnal.fp.unila.ac.id/index.php/ JIA/article/view/2782/2328. [03 Juni 2020]

Giatman M. 2006. Ekonomi Teknik. Raja Grafindo Persada. Jakarta.

Kadariah. 2001. Evaluasi Proyek: Analisis Ekonomis. Lembaga Penerbitan Fakultas Ekonomi Universitas Indonesia. Jakarta.

Khafsah, Warsito SH, dan Prastiya RA. 2018. Analisis kelayakan usaha secara finansial dan efisiensi produksi Peternakan Sapi Perah PT. Fructi Agri Sejati Kabupaten Jombang. JMV, 1(3): 113-119. http://e-journal.unair.ac.id/ JMV/article/view/942 [10 Mei 2019]

Labodu RP, Wantasen E, Massie MT, dan Oroh FNS. 2015. Analisis finansial peternakan sapi perah rakyat di Kota Tomohon (Studi Kasus Di Kelompok Ramulu Sangkor). JZ, 35 (2): 275-

279.https://ejournal.unsrat.ac.id/index.php/zot ek/article/download/8465/8043. [06 Maret 2020]
Mona QT, Lestari DAH, dan Situmorang S. 2014. Analisis pendapatan dan tingkat kesejahteraan rumah tangga peternak sapi perah anggota Koperasi Peternakan Bandung Selatan (KPBS) Pangalengan. Jurnal Ilmu Ilmu Agribisnis, 2 (2): $109-117$. http://jurnal.fp.unila.ac.id/index.php/JIA/articl e/view/734/675. [03 Juni 2020]

Pahlevi R, Zakaria WA, dan Kalsum U. 2014. Analisis kelayakan usaha agroindustri kopi luwak di Kecamatan Balik Bukit Kabupaten Lampung Barat. JURNAL ILMU ILMU AGRIBISNIS, 2 (1): 48-55. http://jurnal.fp.unila.ac.id/index.php/JIA/articl e/view/560/522. [03 Juni 2020]

Poetri NA, Basith A, dan Wijaya NH. 2014. Analisis kelayakan pengembangan usaha peternakan sapi perah KUNAK (Studi Kasus Usaha Ternak Kavling 176, Desa Pamijahan Kab. Bogor). JMO, 5 (2): 122-138. https://journal.ipb.ac.id/index.php/jmo/article/ view/12147. [06 Maret 2020]

Rianzani C, Kasymir E, dan Affandi MI. 2018. Strategi pengembangan usaha ternak sapi perah kelompok tani Neang Mukti di Kecamatan Air Naningan Kabupaten Tanggamus. Jurnal Ilmu Ilmu Agribisnis, 6 (2): 179-186. https://jurnal.fp.unila.ac.id/index.php/JIA/artic le/view/2784/2330. [10 Mei 2019] 